\title{
Aksjologia Europejskiej Partii Ludowej
}

Partie chrześcijańsko-demokratyczne działające obecnie w Europie zrzeszyły się w federację, która przyjęła nazwę - Europejska Partia Ludowa (European People's Party). EPL powstała w 1976 roku, a od 1979 roku występuje pod obecną nazwą. Ma ona charakter transnarodowej partii politycznej. W jej skład wchodzą centroprawicowe regionalne oraz narodowe partie polityczne z całej Europy, które określają się jako chrześcijańsko-demokratyczne lub wywodzą swoje tradycje z ruchu chadeckiego (nazywane potocznie ,partiami siostrzanymi” - sister parties) (Kaleta, Karaś, 2008, s. 312-313). Obecnie w Parlamencie Europejskim EPL tworzy najliczniejszą frakcję (EPP Group). Od chwili swojego powstania miała ona wyraźnie określone oblicze ideowe, tzn. odwoływała się do idei chrześcijańsko-demokratycznych. Jej program polityczny opiera się m.in. na takich wartościach i zasadach jak godność osoby ludzkiej, wolność, odpowiedzialność, solidarność, sprawiedliwość, prawa człowieka, demokracja, rządy prawa, równość, subsydiarność. Przywiązanie eurochadeków do wartości i powoływanie się na nie sprawiło, że EPL zaczęła sama siebie określać mianem „partii wartości” (a political party of values) (EPL, 1992, p. 165).

Przedmiotem analiz stanowiących podstawę dla rozważań zawartych w niniejszym artykule stały się dokumenty programowe EPL przyjęte na jej ostatnich czternastu kongresach, poczynając od kongresu najbardziej znaczącego od czasu obalenia komunizmu, odbywającego się w 1992 roku w Atenach, na którym uchwalono „Program Podstawowy" (Basic Programme), aż do kongresu, który miał miejsce w 2014 roku w Dublinie. Celem analizy dokumentów programowych EPL była próba odpowiedzi na pytanie, w jaki sposób, w ciągu badanego okresu, EPL prezentowała w swoich dokumentach programowych przyjęte przez siebie wartości. Uszczegółowienie tego problemu stanowiły pytania o sposób ugruntowania wartości, racjonalizację działań politycznych z wykorzystaniem wartości, sposób nadawania odświętnego charakteru wartościom, traktowanie wartości jako funkcjonalnych składników systemu politycznego, sposób prezentowania wartości w kontekście gry o władzę.

\section{Teoria wartości politycznych}

W literaturze przedmiotu akceptuje się pogląd, iż w analizie wartości należy wyróżnić warstwę ocenną. Ocenny charakter wartości uzewnętrznia się w formie preferencji, poglądów i postaw wynoszących pewien stan rzeczy nad inny. Działania selektywne, różnicujące elementy otoczenia i preferujące jedne z nich, a deprecjonujące inne, tworzą podstawy podmiotowego działania jednostek/grup. Szczególną interpretację tezy o współzależności między wartością a wyrażającymi ludzkie pragnienia i zaintereso- 
wania zachowaniami wartościującymi przedstawił twórca instrumentalizmu J. Dewey. Twierdzi on, że wartości są faktami z zakresu ludzkiego doświadczenia i z tego względu należą wyłącznie do świata empirycznego. Zredukował on problem wartości do skuteczności, a wartość do instrumentu realizacji konkretnych celów (Dziubka, 1999, s. 135).

Instrumentalizację wartości można też rozumieć w sposób, jaki zaproponował J. H. Kołodziej, czyli jako możliwość podmiotowego konfigurowania proporcji i akcentów między poszczególnymi typami i odmianami wartości oraz podmiotowego kształtowania hierarchii konkretnych wartości, w kontekście ujawniania ich w danej sytuacji społecznej. Kołodziej wyróżnił kilka mechanizmów społecznej instrumentalizacji wartości. Po pierwsze, wartości mogą być przedstawiane jako odczuwane (subiektywnie, emocjonalnie, są bardziej atrakcyjne dla podmiotu) bądź jako uznawane (intersubiektywnie). Po drugie, wartości mogą być prezentowane jako odświętne, uroczyste w przeciwieństwie do codziennych i zwyczajnych. Po trzecie, społeczeństwo może wzmacniać wyobrażenie wartości albo jako celów (wartości ostatecznych) albo jako środków do realizacji celu (Kołodziej, 2011, s. 87-94).

Za cenny poznawczo kierunek teoretyczny, podejmujący problematykę wartości w związku z pojęciem, istotą i funkcjami systemu politycznego, uważa się analizę funkcjonalna. Zdaniem reprezentanta tego kierunku T. Parsonsa wartości społeczne stanowią konceptualizację pożądanego systemu społecznego. W jego teorii zasadnicze znaczenie wartości polega na utrzymaniu integralności i efektywności systemu. Inny przedstawiciel tego kierunku, D. Easton, postrzega wartości polityczne jako normatywne wzorce ludzkich wyborów (Dziubka, 1999, s. 136-137). J. H. Kołodziej, omawiając ujęcie funkcjonalne, zwraca uwagę, że wartości mogą zostać zredukowane do praktycznych mechanizmów politycznych mających zagwarantować urządzenie dobrego życia dla obywateli. Kołodziej zauważa ponadto, że wartości polityczne bywają traktowane jako kryteria racjonalności działań politycznych, tzn. legitymizują podejmowane działania polityczne (Kołodziej, 2011, s. 124-127).

M. Piechowiak koncentruje się z kolei na metaaksjologii, czyli poziomie aksjologii, który można wyróżnić dzięki pytaniu, dlaczego coś uznajemy za wartość, jak wartości są ugruntowane, jaki jest ich status ontologiczny (Piechowiak, 2003, s. 5-29).

Teoria wartości politycznych zwraca ponadto uwagę na to, iż w systemie wartości politycznych centralne miejsce zajmuje władza polityczna. Pewne wartości i dobra mogą być osiągnięte wyłącznie przez uzyskanie i sprawowanie władzy politycznej. Z tego względu sama władza polityczna jest traktowana jako wartość (Dziubka, 1999, s. 139).

W teorii wartości politycznych zwykle wyróżnia się kilkanaście typów wartości (makrospołeczne i mikrospołeczne; autoteliczne i instrumentalne; pierwotne i wtórne; realizowane i deklarowane; racjonalne i nieracjonalne; trwałe i efemeryczne; pozytywne i negatywne) oraz kilka spełnianych przez nie funkcji: integracyjna, stabilizującą, regulacyjną, inspiracyjną i dyrektywną (Dziubka, 1999, s. 142-151).

\section{Badania nad Europejską Partią Ludową}

Jednym z aspektów badań prowadzonych nad Europejską Partią Ludową jest ujęcie historyczno-politologiczne. W jego ramach prowadzi się studia nad początkami 
EPL, powiększaniem się EPL o nowych członków oraz zachowaniem EPL na różnych etapach integracji europejskiej. Badania te koncentrują się ponadto nad strukturą ugrupowania, organizacją jego pracy oraz dokumentami programowymi (Jansen, Hecke, 2011).

Większość politologów skupia się jednak przede wszystkim na funkcjonowaniu frakcji EPL w Parlamencie Europejskim. Refleksja w tym zakresie prowadzona jest nad wewnętrznym układem sił w EPL, sposobami głosowania członków frakcji EPL, skutecznością polityki EPL w Parlamencie Europejskim oraz relacjami EPL z innymi ugrupowaniami. Szczególnie duże zainteresowanie badaczy wzbudziło budowanie przez EPL aliansów politycznych, a zwłaszcza rozszerzenie frakcji EPL o partie, które nie wywodziły się z chrześcijańsko-demokratycznego nurtu oraz strategia frakcji EPL, dzięki której stała się ona największym ugrupowaniem w Parlamencie Europejskim (Johansson, 1997; Gagatek, 2007; Lynch, Whitaker, 2008).

Studia nad EPL obejmują także wartości przyjęte przez to ugrupowanie. Przede wszystkim pokazywane są chrześcijańsko-demokratyczne źródła owych wartości. Po drugie, bada się, w jaki sposób przyjęte przez EPL wartości przekładane są na praktykę. W tym zakresie badacze wykazują szczególne zainteresowanie kryzysem, który zaczął się w Europie w 2008 r. (Tensen, Novotný, Reho, Hecke, 2014).

\section{Katalog wartości EPL}

EPL wyraźnie określiła, jakimi wartościami kieruje się w swoim myśleniu i działaniu politycznym. W każdym z najważniejszych dokumentów EPL znajduje się bowiem rozdział bądź wydzielona część poświęcona aksjologii. EPL nie przyjęła jednak jednej nazwy katalogu uznanych przez siebie wartości. W jej programie z 1992 r. nazywane są one wartościami podstawowymi/fundamentalnymi (fundamental values), od $1999 \mathrm{r}$. wartościami podstawowymi/zasadniczymi (basic values), zaś od $2001 \mathrm{r}$. wartościami najważniejszymi/kluczowymi (core values) lub po prostu wartościami (values).

W ciagu ostatnich 22 lat można zauważyć zmiany w zakresie zawartości katalogu wartości przyjętych przez EPL jako podstawowe. W „Programie Podstawowym” przyjętym w 1992 roku stwierdzono, że właściwy kierunek politycznego myślenia i działania, zapewni EPL oparcie się na takich podstawowych wartościach (fundamental values) jak: wolność, odpowiedzialność, podstawowa równość (fundamental equality), sprawiedliwość i solidarność (EPL, 1992, p. 108). W rozdziale poświęconym podstawom aksjologicznym oprócz wymienionych wyżej wartości znalazła się jeszcze godność człowieka, zasada demokracji i subsydiarności. Nie zostały one jednak nazwane wartościami podstawowymi (EPL, 1992, p. 101, 141, 291).

W programie EPL na lata 1999-2004 do wspomnianego wyżej katalogu wartości podstawowych (basic values), zostały dołączone: chrześcijańskie dziedzictwo kulturowe, prawa człowieka oraz ideały demokratyczne (EPL, 1999, p. 10). Program z 2001 roku katalog najważniejszych wartości (core values), którymi kieruje się EPL, poszerza o godność osoby ludzkiej, demokrację oraz rządy prawa (EPL, 2001, p. 006). Natomiast w programie z 2006 roku, obok najważniejszych dla EPL wartości, zostały wymienione jeszcze inne wartości i zasady, które EPL uznaje i ceni, lecz nie zalicza 
do katalogu wartości podstawowych. W programie tym czytamy: „Wartości te (tzn. godność osoby ludzkiej, wolność i odpowiedzialność, podstawowa równość, sprawiedliwość, subsydiarność i solidarność) są wspólne dla społeczeństw Państw Członkowskich, w których dominuje demokratyczny pluralizm, rządy prawa, niedyskryminacja, tolerancja, prywatna własność i oparcie się na społecznej gospodarce rynkowej. Stawiając czoła trendom w życiu społeczno-kulturalnym zachodniego świata, Europejska Partia Ludowa zawsze kierowała się tymi wartościami i tradycjami, włączając szacunek dla rodziny, tradycyjnych mniejszości i historycznych regionów oraz kościołów, które od wieków stanowią mocną podstawę europejskiej cywilizacji" (EPL, 2006a, s. 5). Jak widać w programie z 2006 r. pominięto wcześniej uznane za podstawowe chrześcijańskie dziedzictwo kulturowe, prawa człowieka, demokrację i rządy prawa. W dokumencie przyjętym podczas kongresu EPL, odbywającym się w 2009 roku w Warszawie, do wartości uznanych przez EPL za własne, których nie nazwano jednak podstawowymi, dołączono jeszcze „wartości otwartego społeczeństwa”, nie wymieniając przy tym nazwy żadnej z nich (EPL, 2009, s. 3).

Dokumenty EPL z poszczególnych lat ujawniają rozbieżności w terminologii, którą EPL posługuje się w określaniu niektórych swoich wartości oraz w zakresie przyjętej ich hierarchii. W większości dokumentów mowa jest o godności osoby ludzkiej (dignity of the human person), natomiast w programie z 2009 r. używa się określenia „godność istoty ludzkiej” (the dignity of the human being) (EPL, 2009, s. 3), zaś w 2012 roku w katalogu najważniejszych wartości EPL pojawił się zwrot „godność ludzkiego życia na każdym stopniu jego istnienia" (the dignity of human life in every stage of its existence) (EPL, 2012a, p. 005). Stwierdzenie „godność osoby ludzkiej” odsyła do personalizmu, podczas gdy „godność istoty ludzkiej” oraz „godność ludzkiego życia" nie sugeruje takiej koncepcji antropologicznej.

Choć w wielu dokumentach podkreśla się, że najważniejsze wartości EPL są równie istotne, to jednak w programie z $2009 \mathrm{r}$. wbrew tej deklaracji stwierdza się, że godność stanowi centralną wartość (EPL, 2009, s. 3), a w programie z 2012 r. zaznacza się, że sprawiedliwość i solidarność można zrealizować jedynie wtedy, gdy wolność zostanie przez każdego zaakceptowana jako podstawowy wymóg (EPL, 2012a, p. 106, 108).

Dokumenty programowe wyjaśniaja jaką treść EPL wiąże z przyjętymi wartościami podstawowymi. Najbardziej szczegółowo wyjaśnione są wartości, które zostały określone jako fundamentalne w „Programie Podstawowym” z 1992 roku. Według tego dokumentu prawdziwa wolność nie oznacza nieodpowiedzialności i zależności. Jej treścią jest autonomia i odpowiedzialność. Każda osoba jest odpowiedzialna za swoje czyny, nie tylko przed własnym sumieniem, ale również przed wspólnotą i przyszłymi pokoleniami. Równość EPL rozumie przede wszystkim jako reprezentowanie przez każdego człowieka jednakowej godności. Uznanie równości zobowiązuje do szacunku wolności innych, w tym przez ograniczenie własnej wolności. Każdej osobie przysługują jednakowe prawa bez względu na jej pochodzenie, płeć, wiek, rasę, narodowość, religię, przekonania, społeczny status oraz stan zdrowia. Dla EPL sprawiedliwość oznacza zapewnienie warunków niezbędnych dla urzeczywistniania wolności jednostek i wspólnot stosownie do ich natury i celów. Jeden z wymiarów sprawiedliwości stanowi szacunek dla prawa, które powinno opierać się na podstawowych prawach człowieka określonych w międzynarodowych konwencjach. Ponadto sprawiedliwość 
jest równoznaczna z poszanowaniem praw mniejszości przez większość. Bardziej ludzkie relacje w społeczeństwie, zdaniem EPL, mogą zaistnieć dzięki solidarności. Oznacza ona świadomość zależności jednych członków społeczeństwa od drugich połączoną z praktyczną pomocą, zwłaszcza najsłabszym członkom społeczności. Cenioną przez EPL zasadę stanowi subsydiarność, czyli sprawowanie władzy na poziomie, który odpowiada wymaganiom solidarności, skuteczności i udziału obywateli, inaczej mówiąc, tam, gdzie sprawowanie to jest zarówno skuteczne, jak i najbliższe jednostce. Jednocześnie zasada subsydiarności nakazuje, aby wyższy poziom pomagał niższemu, gdy ten nie jest w stanie wypełniać swoich zadań (EPL, 1992, p. 101-155).

\section{Ugruntowanie wartości EPL}

Przyjęte przez EPL wartości zakotwiczone są w określonej antropologii, choć to przekonanie w sposób wyraźny w dokumentach programowych odniesione zostało jedynie w stosunku do wolności i równości. EPL stwierdza jednak, że wszystkie uznane przez siebie wartości traktuje jako wzajemnie zależne. W przyjętej przez EPL antropologii ujmuje się człowieka jako osobę, której przypisuje się szczególną cechę zwaną godnością. Pod tym względem wszyscy mężczyźni i kobiety pozostają równi. Osoba charakteryzuje się ponadto tym, że jest jednostką unikalną, niezastępowalną, której nie można pozbawić jej statusu ontycznego, z natury wolną i otwartą na transcendencję. Osoba stanowi cel życia społecznego i jej dobru powinny zostać podporządkowane wszelkie działania (EPL, 1992, p. 101-106).

W programie z 1992 r. i w kilku innych dokumentach przyjętych na późniejszych kongresach stwierdza się, że przyjęte wartości wywodzi się z tradycji judeochrześcijańskiej (EPL, 1992, p. 101) albo z chrześcijańskiego obrazu człowieka (EPL, 2012a, p. 006). Powiązanie uznanej przez EPL aksjologii i antropologii z tradycją judeochrześcijańska/chrześcijańską sprawia, iż można mówić o przyjętej implicite metafizyce wartości. Warto przy tym zaznaczyć, że w dokumentach programowych EPL słowo „Bóg” pojawia się tylko w dwóch miejscach: gdy mowa jest o działaniu człowieka jako udziale w bożym dziele stworzenia (EPL, 1992, p. 103) oraz gdy stwierdza się, że przekonanie o godności człowieka i związanej z nią jego wyjątkowości jest podzielane zarówno przez wierzących, jak i niewierzących w Boga (EPL, 2012b, p. 2).

W programie z 1997 roku pojawia się po raz pierwszy określenie „chrześcijańskie i humanistyczne wartości” (EPL, 1997, p. 7), zaś w dokumencie z 2001 r. znalazło się stwierdzenie, że partie wchodzące w skład EPL pochodzą z różnych tradycji, zarówno konfesyjnych, jak i świeckich (EPL, 2001, p. 006). Począwszy od 2004 roku EPL znacznie rozbudowuje katalog tradycji, z których wywodzi swoje wartości. W programie z tego roku można przeczytać, że koncepcja człowieka przyjmowana przez EPL ma nie tylko judeochrześcijańską proweniencję, lecz jest wspólna dla antycznego humanizmu, renesansu, reformacji oraz oświecenia (EPL, 2004, s. 4). W dokumentach z kolejnych lat odwołanie się do tych tradycji jest konsekwentnie powtarzane. Korzenie judeochrześcijańskie i oświecenie jako źródła wartości i idei wspominane są najczęściej, natomiast nazwy pozostałych tradycji w niektórych dokumentach nie pojawiają się, ale wówczas w miejscu, gdzie mowa jest o tym, skąd EPL wywodzi 
swe wartości, można odnaleźć inne zwroty, które, jak wydaje się, obejmują pominięte tradycje, jak na przykład „wspólne dziedzictwo kulturowe” czy „starożytna i humanistyczna historia Europy" (EPL, 2009, s. 3).

Powstaje pytanie, czy zakorzenienie uznawanych przez EPL wartości w innych tradycjach niż wymienione w „Programie Podstawowym” z 1992 r. dziedzictwo judeochrześcijańskie, nie pozbawia ich dotychczasowej metafizyki, a w konsekwencji czy nie zmienia ich treści. Jeśli odpowiedź na to pytanie byłaby pozytywna, to oznaczałoby, że wartościom przyjmowanym przez siebie, EPL nie przypisuje ontologicznego statusu obiektywnie istniejących własności, a jedynie status kulturowo-historyczny. Dotychczasowe dokumenty programowe EPL na to nie wskazuja. Jednak opisane wyżej zmiany, które dokonały się w programie EPL, stwarzają możliwość wprowadzenia w przyszłości nowych treści przy zachowaniu niezmienionego kanonu przyjętych wartości.

\section{Wartości jako kryteria racjonalności działań politycznych}

W dokumentach programowych EPL wartości przedstawiane są w taki sposób, by uprawomocnić działania polityczne podejmowane przez to ugrupowanie. W tym celu, wspominając przyjęte przez EPL wartości, stwierdza się, że zakotwiczone są one w tradycji judeochrześcijańskiej i chrześcijańskim obrazie człowieka. W „Programie Podstawowym" z 1992 r., w miejscu, gdzie mowa jest o wartościach, znaleźć można odwołanie do chrześcijańsko-demokratycznej myśli i stwierdzenie, że na przyjętych wartościach opiera się chrześcijańsko-demokratyczna wizja społeczeństwa (EPL, 1992, p. 108, 141). W programie z 2004 r. deklarowane jest przywiązanie do personalizmu chrześcijańskiego inspirowanego filozofią Jacquesa Maritaina, Gabriela Marcela i Emmanuela Mouniera (EPL, 2004, s. 4), w programie z 2006 i 2009 r. stwierdza się, że EPL broni tych samych wartości i ideałów, które podzielali chadeccy politycy: Jean Monnet, Robert Schuman, Alcide de Gasperi i Konrad Adenauer (EPL, 2006a, s. 5; EPL, 2009, s. 2).

W dokumentach programowych EPL stwierdza się, że EPL swoje myślenie i działanie opiera na „fundamentalnych” oraz „uniwersalnie stosowanych” wartościach (EPL, 1992, p. 108). Ponadto, zwraca się uwagę, iż w czasie, kiedy europejskie demokracje doświadczają kryzysu wartości, przyjęcie wartości należących do chadeckiego kanonu pozwala EPL uzyskiwać motywację do podejmowania działań, a także daje siłę do ich realizacji i pewność co do słusznego kierunku. Przede wszystkim dlatego, że są to stałe wartości (firm values), od wieków stanowiące mocną podstawę europejskiej cywilizacji i jak się można domyślać, jako takie, są wartościami sprawdzonymi. Dzięki nim EPL ma poczucie wypełniania misji, która polega na realizowaniu uniwersalnego przesłania. Bez nich byłaby ona „pozbawiona duszy czy przyszłości” i stała się niczym więcej jak narzędziem władzy. Politycy EPL traktują swoje wartości jako godne zaufania kryterium, pozwalające zorientować się, co należy zachować, co ulepszyć, czego unikać, a co zwalczać. Posiadanie takiej pewności ma szczególne znaczenie w obliczu współczesnych gwałtownych przemian społecznych, zwłaszcza zaś procesów globalizacji, które stanowią poważne wyzwanie dla tożsamości wszystkich partii 
politycznych. Chadeckie wartości wzmacniają pewność EPL odnośnie jej tożsamości, ponieważ dzięki nim odróżnia się ona od innych partii: liberalnych, socjalistycznych i ekologicznych (EPL, 1992, s. 2 i p. 166; EPL, 2001, p. 601).

Opisany powyżej sposób prezentacji wartości służy także wydobyciu ich wymiaru uroczystego, odświętnego. Stanowi wyraz troski o „fasadę” tego ugrupowania, czyli pożądany obraz w oczach innych. O zamiarze nadania uroczystego wymiaru wartościom, które uznaje EPL, można mówić także ze względu na zabiegi służące podkreśleniu moralnego charakteru tych wartości. W sposób wyraźny taki charakter został w dokumentach EPL przypisany wolności. Zapisano w nich, że uznanie i przyjęcie wolności implikuje odpowiedzialność człowieka za siebie, własne czyny oraz przyszłość. Człowiek jest odpowiedzialny przed bliźnimi i stworzeniem. Z wolnością związane jest również powołanie człowieka do wniesienia własnego wkładu w boże dzieło stworzenia, co oznacza m.in. obowiązek udziału w budowie społeczeństwa (EPL, 1992, p. 103, 104, 110).

\section{Wartości jako funkcjonalne składniki systemu politycznego}

W oficjalnych dokumentach EPL przyjęte przez nią wartości niezwykle rzadko bywają ukazywane jako cele same w sobie. Na przykład w programie przyjętym w Warszawie w 2009 r. mowa jest o wizji, którą chce zrealizować EPL, a jeden z jej elementów stanowi solidarność (EPL, 2009, s. 4). Znacznie częściej wartości przedstawiane są w sposób instrumentalny, tzn. jako środki wiodące do celu. Zwykle używa się stwierdzenia, że postulowane działanie czy rozwiązanie „opiera się” na przyjętych przez EPL wartościach. Na przykład w Programie Podstawowym z 1999 r. stwierdza się, że EPL chce budować świat oparty na wolności i solidarności (EPL, 1992, p. 108). W dokumencie z 2006 r. pojawia się stwierdzenie, że „nasze polityczne metody oparte są na pomocniczości i solidarności” (EPL, 2006a, p. 131). We wspomnianym programie z 2009 r. mówi się o społeczeństwie opartym na indywidualizmie, wolności i spójności społecznej oraz gospodarce opartej na wartościach (EPL, 2009, s. 4). W tym samym dokumencie zapisano, że EPL wykazuje niezachwianą wiarę w europejski ideał oraz chce budować Unię Europejską na uznawanych przez siebie wartościach (EPL, 2009, s. 4).

Wartości uznane i przyjęte przez EPL przedstawiane są nie tyle jako abstrakcyjne ideały, ile ukazuje się ich ścisłe powiązanie z interesami wspólnoty politycznej. Na przykład w programie EPL z 1997 r. postuluje się rozszerzenie Unii Europejskiej na Wschód i o kraje śródziemnomorskie. W ten sposób EPL chce urzeczywistniać solidarność z krajami mniej zasobnymi, promować swoje wartości, m.in. prawa człowieka i demokrację, a jednocześnie integrację nowych krajów traktuje jako najlepszy środek pozwalający uniknąć konfliktów. Włączenie tych krajów do Unii Europejskiej powiększy bowiem przestrzeń stabilnej demokracji, rządów prawa, gospodarki rynkowej i w efekcie przyczyni się do bezpieczeństwa oraz dobrobytu całej Unii oraz regionu (EPL, 1997, p. 10). W programie z 2001 r. EPL wzywa do solidarności z państwami afrykańskimi. Jej wyrazem ma być promocja praw człowieka, demokracji, wolnego rynku oraz włączenie ich w światowy obieg gospodarczy. Postulat ten umieszcza 
w kontekście stwierdzenia, iż z krajów, którym trzeba pomóc, pochodzi wielu uchodźców, co niepokoi Europę (EPL, 2001, p. 525). W dokumencie z 2012 r. stwierdza się, że EPL była i będzie zdolna do działań na rzecz większej stabilności i pomyślności Europy dzięki wierności własnym wartościom. W tym samym dokumencie EPL zadeklarowała, że zamierza, opierając się na przyjętych przez siebie wartościach, wyznaczać polityczne strategie, które pomogą Unii Europejskiej przezwyciężyć kryzys (EPL, 2012a, p. 010).

W dokumentach programowych EPL można ponadto wskazać fragmenty, w których wartości zostały zredukowane do praktycznych mechanizmów politycznych mających zagwarantować urządzenie dobrego życia dla obywateli. Na przykład w Programie Podstawowym z 1999 r. stwierdza się, że przyjęta przez EPL koncepcja człowieka i społeczeństwa skupia się na integralnym rozwoju jednostki, zaspokajając w ten sposób jej materialne, kulturalne i duchowe potrzeby (EPL, 1992, p. 131). Swoją antropologię EPL przeciwstawia ujęciom człowieka w ideologii liberalnej, ekologicznej i socjalistycznej, ponieważ dokonują one redukcji potrzeb człowieka, jedynie zaś EPL, w jej przekonaniu, ukazuje je najpełniej, co oznacza, że jedynie działania oparte na jej programie prowadzą do zapewnienia człowiekowi szczęścia (wellbeing) (EPL, 1992, s. 2, p. 115, 128-131).

Wartości jako mechanizmy gwarantujące urządzenie dobrego życia dla obywateli zostały jednak zaprezentowane w taki sposób, aby pokazać, że wyznaczają one jedynie kierunek działania, a nie nakazują ściśle określone postępowanie. To ujęcie zostało podyktowane przede wszystkim realizmem, któremu hołduje EPL. Ugrupowanie to deklaruje, iż nie proponuje idealnych rozwiązań, ponieważ nie jest tak dogmatyczne jak partie wyznające ideologię liberalną czy socjalizm, ani też nie podchodzi do problemów w sposób czysto pragmatyczny. Zdaniem EPL prawda ma charakter transcendentny i jako taka nie jest całkowicie dostępna człowiekowi. EPL stwierdza, że nie posiada gotowych recept na wszelkie problemy, lecz szuka różnych rozwiązań, aby umożliwiać jednostkom integralny rozwój i życie społeczne czynić bardziej ludzkim. Przekonuje, iż lepiej niż partie opierające się na ideologiach jest przystosowana do współczesnych zmian, gdyż jej wartości nie proponują utopijnych wizji idealnego społeczeństwa. Pozwalają natomiast wyzwalać w jednostkach ich potencjał twórczy i konstruktywne podejście do problemów (EPL, 1992, s. 2-3, art. 105, 131, 132).

Realizacja wartości przyjętych przez EPL oznacza, że należy pogodzić działania o różnych kierunkach. EPL wskazuje z jednej strony na autonomię jednostki i przysługujące jej indywidualne prawa, $z$ drugiej zaś podkreśla przynależność każdego do społeczności i wynikające stąd obowiązki względem niej. Nakazuje szacunek dla ludzkiej wolności, jednak jest ona ograniczona moralnie. EPL odrzuca zarówno egoistyczny indywidualizm, jak i kolektywizm. Opowiada się za pielęgnowaniem tradycji, a jednocześnie za nowoczesnością. Próbuje pogodzić europejską integrację z narodowymi i regionalnymi interesami. Zdaniem EPL jednostki muszą wziąć odpowiedzialność za własne życie, ale mogą też spodziewać się zorganizowanej solidarności. EPL próbuje też pogodzić interesy pracodawców i pracowników. Opowiada się za ekonomicznym wzrostem przy jednoczesnym postępie społecznym. Uważa, że społeczeństwa europejskie powinny być solidarne z uchodźcami, ale jednocześnie mają prawo bronić się, jeśli ci stanowią zagrożenie. Dopuszcza badania biomedyczne, ale muszą być one pro- 
wadzone w etycznych ramach. Rozwój ekonomiczny musi być zrównoważony, tzn. decyzje ekonomiczne muszą brać pod uwagę wymogi ochrony środowiska. EPL takie podejście nazywa polityką równowagi i jest przekonana, że jest to polityka przyszłości. Jej zdaniem w zmieniającej się rzeczywistości nie sposób prowadzić politykę, która jest oparta na dogmatycznym myśleniu czy założeniach ideologicznych (EPL, 1999, s. 2). W literaturze politologicznej polityka prowadzona przez partie chrześcijańsko-demokratyczne określana jest niekiedy mianem „trzeciej drogi”. Wydaje się, że biorąc pod uwagę to, co powiedziano powyżej, nazwa ta adekwatna jest do programu EPL. Politykę „trzeciej drogi” postrzega się jako działanie, które oscyluje między socjaldemokratyzmem a konserwatyzmem, między liberalizmem a kolektywizmem. Nie oznacza to jednak, że odmawia się jej swoistego charakteru. Jej rysem charakterystycznym jest właśnie próba zachowania równowagi pomiędzy podejściami skrajnymi (Karolczak, 1996, s. 13).

\section{Wartości w kontekście gry o władzę}

W 1989 roku przewaga socjalistów nad frakcją EPL w Parlamencie Europejskim znacznie się powiększyła. Kierownictwo EPL i liderzy jej partii krajowych zrozumieli, że bez otwarcia się na partie spoza nurtu chadeckiego ów dystans się nie zmniejszy. Ta strategia była kontynuowana również w badanym okresie, czyli po roku 1992. Co więcej, EPL postawiła sobie za cel bycie największym ugrupowaniem politycznym w Parlamencie Europejskim. Nie był to wyraz jedynie jej ambicji politycznych, ale również działanie pod wpływem zachęt instytucjonalnych jakie stwarza Parlament Europejski. Cała struktura polityczna Parlamentu, w tym podział wszelkich dóbr dostępnych dla jego frakcji politycznych, opiera się na podziale na podstawie liczby posłów zasiadających we frakcji. Podział wpływowych stanowisk, na przykład przewodniczących komisji parlamentarnych dokonywany jest na podstawie metody d'Hondta, która sprzyja dużym frakcjom. Duże frakcje mają ponadto lepszą pozycję przetargową w wewnątrzparlamentarnej rywalizacji politycznej. W interesie zatem dużych frakcji dokonuje się konsolidacja systemu partyjnego Parlamentu Europejskiego.

Po kolejnych rozszerzeniach Unii Europejskiej w szeregi frakcji EPL zostały przyjęte partie konserwatywne z Grecji, Hiszpanii, Włoch, Danii oraz Wielkiej Brytanii, przy czym duńscy i brytyjscy konserwatyści uzyskali status członków stowarzyszonych, co oznaczało, że nie są związani programem politycznym EPL. W ramach strategii maksymalizacji wpływów w Parlamencie Europejskim w szeregi frakcji EPL w 1996 roku przyjęto nawet dziewięciu posłów Partii Socjaldemokratycznej (Gagatek, 2007, s. 104-123).

W kontekście powyższych działań EPL może pojawić się pytanie, czy zmiana strategii EPL w ramach prowadzonej gry o władzę dotyczyła również wymiaru aksjologicznego dekretowanego w dokumentach programowych EPL. Jedyny ślad, który mógłby świadczyć o tym, to wspomniane już rozszerzenie katalogu tradycji, stanowiących źródło podzielanych przez EPL wartości oraz idei. Od 2004 roku w dokumentach programowych znalazły się zapisy mówiące, iż EPL odwołuje się nie tylko do tradycji judeochrześcijańskiej, lecz także dziedzictwa antycznego humanizmu, renesansu, re- 
formacji oraz oświecenia. Zmiana ta mogłaby świadczyć o zamiarze otwarcia się na różnorodność tradycji w związku z przyjęciem w szeregi EPL partii nieodwołujących się do idei chadeckich.

Analiza zmian aksjologii w programach EPL ujawnia też inną koincydencję. Rozszerzenie katalogu źródłowych tradycji EPL w 2004 r. zbiega się w czasie z procesem uchwalania Traktatu ustanawiającego Konstytucję dla Europy. W trakcie prac nad nim miała miejsce debata, w której przedmiot sporu stanowiła między innymi kwestia odwołania się do chrześcijaństwa. Niektórzy uczestnicy debaty przekonywali, że można wskazać więcej źródeł kultury europejskiej niż tylko chrześcijaństwo, np. oświeceniowy humanizm. Podjęto również próbę, aby na wzór polskiej konstytucji, odzwierciedlić w preambule Traktatu zróżnicowanie religijne i światopoglądowe Europejczyków, dzięki temu nikogo nie dyskryminując czy wykluczając (Mazurkiewicz, 2005, s. 218). Rozwiązanie zastosowane w programie EPL z 2004 r. współbrzmi z tymi propozycjami i pojawiło się w tym samym czasie co one.

Badacze działalności EPL, jak na przykład Simon Hix, Abdul Nouiy i Gerard Roland, wykazali, że w okresie po 1992 r., pomimo że EPL przyjęła nowych członków, którzy nie wywodzili się z tradycji chrześcijańsko-demokratycznej, nie utraciła ona swej spójności ideowej. Po pierwsze dlatego, że już w 1998 r. w EPL pojawiły się wewnętrzne ruchy na rzecz zachowania chadeckiej tożsamości. Posłowie frakcji EPL niezadowoleni z nowej strategii kierownictwa utworzyli tzw. Grupę Atena, która w ramach frakcji miała walczyć o powrót do tradycyjnych wartości chadeckich, odwołując się do „Programu Podstawowego”, uchwalonego w 1992 roku na IX Kongresie EPL w Atenach (Gagatek, 2007, s. 104-123). Po drugie dlatego, że w wyniku kolejnych zmian traktatowych zwiększono uprawnienia Parlamentu Europejskiego, co sprzyjało zachowaniu spójnego bloku w celu współzawodnictwa z innymi frakcjami, mającego na uwadze realizację własnego programu (Gagatek, 2007, s. 121-122).

W dokumentach programowych EPL można odnaleźć refleks owej troski o zachowanie chadeckiej tożsamości ugrupowania. Stanowią go fragmenty, w których EPL ustosunkowuje się w duchu tej tożsamości do tzw. kwestii wrażliwych etycznie. W programie przyjętym w $2001 \mathrm{r}$. EPL zapewnia, że dąży do poszanowania prawa do życia oraz niepowtarzalności każdej istoty ludzkiej od poczęcia do śmierci. EPL opowiada się ponadto za traktowaniem embrionu jako osoby ludzkiej. Postuluje, by badania biomedyczne były prowadzone w określonych etycznych ramach (EPL, 2001, p. 316). W programie z 2004 r. EPL sprzeciwia się eutanazji, eugenice oraz klonowaniu ludzi (EPL, 2004, s. 5). Odrzuca aborcję jako „rozwiązanie problemu”, jaki stwarza niechciana ciąża. Chce natomiast promować programy i inicjatywy pomagające rodzicom i rodzinom przyjąć każde dziecko, zwłaszcza w sytuacji trudnej bądź niechcianej ciąży. Zdaniem EPL nie do zaakceptowania jest sytuacja, gdy wywiera się presję na rodziców, którzy zaakceptowali i zdecydowali się przyjać dziecko upośledzone. Diagnostyka prenatalna może być stosowana jedynie wtedy, gdy rodzice odbyli stosowne konsultacje. Mają oni prawo do profesjonalnego, ludzkiego i chroniącego życie poradnictwa, które pomoże im dokonać najlepszego w danych warunkach wyboru (EPL, 2004, s. 5).

W swoim programie z $2006 \mathrm{r}$. EPL podkreśla znaczenie rodziny w społeczeństwie oraz postuluje konieczność pomocy dla niej. Proponuje przede wszystkim zachęty 
ekonomiczne dla rozwoju rodzin, zmniejszenie obciążeń podatkowych dla rodzin o niskich dochodach oraz usprawnienie służb socjalnych działających na rzecz rodziny (EPL, 2006b). Należy jednak dodać, że pomimo docenienia roli rodziny w społeczeństwie i sformułowania powyższych postulatów małżeństwo i rodzina nie zostały wpisane przez EPL do katalogu jej wartości podstawowych.

\section{Bibliografia}

Dziubka K. (1999), Wartości polityczne, w: Studia z teorii polityki, t. 1, red. A. W. Jabłoński, L. Sobkowiak, Wrocław.

EPL (1992), Basic Programme adopted by the IXth EPP Congress, Athens, November 1992, http:// epp.eu/library.

EPL (1997), We are all part of one world. XII Congress of the European People's Party, Toulouse, 9-11 November 1997, http://epp.eu/library.

EPL (1999), On the Way to the 21st Century. EPP Action Programme 1999-2004 adopted by the XIII EPP Congress, 4-6 February1999, Brussels, http://epp.eu/library.

EPL (2001), A Union of Values - final text agreed at XIV Congress, Berlin 2001, http://epp.eu/library.

EPL (2004), European People's Party Action Programme 2004-2009 approved by EPP Congress, Brussels, of 4-5 February 2004, http://epp.eu/library.

EPL (2006a), For a Europe of the Citizens: Priorities for a Better Future ("Rome Manifesto"). Adopted by the EPP Congress, Rome, 30-31 March 2006, http://epp.eu/library.

EPL (2006b), Supporting the family. Resolution adopted by the EPP Congress, Rome, 30-31 March 2006, http://epp.eu/library.

EPL (2009), Silni dla ludzi. Dokument wyborczy EPL przyjęty przez Kongres EPL w Warszawie 29-30 kwietnia 2009, http://epp.eu/library.

EPL (2012a), Party Platform. EPP Statutory Congress, 17-18 October 2012, Bucharest, Romania, http://epp.eu/library.

EPL (2012b), Manifesto. EPP Statutory Congress, 17-18 October 2012, Bucharest, Romania, http:// epp.eu/library.

Gagatek W. (2007), Geneza i ewolucja frakcji Europejskiej Partii Ludowej (Chrześcijańskich Demokratów) w Parlamencie Europejskim, „Studia Polityczne”, nr 20.

Jansen T., Hecke van S. (2011), At Europe's Service. The Origins and Evolution of the European People's Party, Brussels.

Johansson K. (1997), Transnational Party Alliances. Analysing the Hard-Won Alliance Between Conservatives and Christian Democrats in the European Parliament, Lund.

Kaleta P., Karaś T. (2008), Europejska Partia Ludowa jako europejska transnarodowa federacja partii politycznych, „Przegląd Sejmowy”, nr 2.

Karolczak K. (1996), Od chadecji do syjonizmu. Szkice o myśli politycznej XX wieku, Warszawa.

Kołodziej J. H. (2011), Wartości polityczne. Rozpoznanie, rozumienie, komunikowanie, Kraków.

Lynch P., Whitaker R. (2008), A Loveless Marriage: The Conservatives and the European People's Party, „Parliamentary Affairs”, vol. 61, no. 1.

Mazurkiewicz P. (2005), Wspólne wartości w Traktacie ustanawiającym Konstytucję dla Europy, w: Religia - tożsamość - Europa, red. P. Mazurkiewicz, S. Sowiński, Wrocław.

Piechowiak M. (2003), Aksjologiczne podstawy Karty Praw Podstawowych Unii Europejskiej, „Studia Prawnicze", nr 1. 
Tensen B., Novotný V., Reho F. O., Hecke van S. (2014), The Christian Democratic Origins of the European People's Party: values and relevance for policies, „European View”, no. 13.

\section{Streszczenie}

Europejska Partia Ludowa nazywana jest „partią wartości” z tego powodu, iż w swoich programach i działaniu odwołuje się do chrześcijańsko-demokratycznych wartości. Analiza dokumentów programowych EPL z lat 1992-2014 ujawniła, że EPL prezentuje swoje wartości na różne sposoby. Przyjętym przez siebie wartościom nadaje ona odświętny charakter, wartości te wykorzystuje do racjonalizacji działań politycznych oraz traktuje je jako funkcjonalne składniki systemu politycznego. Dokumenty programowe EPL w miejscach, gdzie mowa jest o wartościach, zawierają również ślad gry o władzę, w jakiej uczestniczyła EPL w badanym okresie. Ponadto analiza dokumentów pokazuje, że w EPL pojawiła się tendencja do redefinicji tożsamości tego ugrupowania politycznego. Stało się to za sprawą osłabienia czy nawet zanegowania dotychczasowej metafizyki, w której zakotwiczone były wartości stanowiące podstawę tożsamości EPL.

Słowa kluczowe: wartości, wartości polityczne, aksjologia, Europejska Partia Ludowa

\section{The axiology of the European People's Party}

\section{Summary}

The European People's Party is called the "party of values" due to the fact that it refers to Christian democratic axiology in its programmes and actions. An analysis of programming documents of the EPP from the 1992-2014 period has shown that the EPP presents its values in various ways. The adopted values are given a festive character, they are being used to rationalise political actions and treated as functional elements of the political system. In the programming documents of the EPP, in passages which refer to values, one may find the traces of the power struggle in which the EPP participated during the analysed period. In addition to the above, a review of the said documents reveals that the EPP has been experiencing a tendency to redefine the identity of this political group. This happened as a result of weakening or even negating the hitherto prevailing metaphysics, in which the values which constituted the foundation of the identity of the EPP were anchored.

Key words: values, political values, axiology, European People’s Party 